\title{
THE STORY OF ABRAHAM'S PREACHING IN ALQURAN
}

\author{
Didin Faqihudin \\ STAIN Datokarama Palu, Jl. Diponegoro 23 Palu \\ e-mail: faqih_75@yahoo.com
}

\begin{abstract}
Ibrahim, adalah Nabi yang namanya diagungkan oleh umat Yahudi, Kristen, dan Islam, suatu hal yang tidak dimiliki oleh nabi-nabi lain. Ketiga penganut agama tersebut memiliki kisah tersendiri tentang Ibrahim berdasarkan pada kitab suci mereka masing-masing, dan tentu saja tidak menutup kemungkinan adanya perbedaan antara satu dengan lainnya. Artikel ini, berupaya memaparkan satu sisi dari sejarah kehidupan Ibrahim, yakni bagaiamana Ibrahim menyampaikan pesan Tuhan kepada kaumnya. Permasalahan ini akan dibahas dalam perspektif Islam, dengan merujuk kepada Alquran sebagai sumber utamanya.
\end{abstract}

Abraham is a prophet whose name is celebrated by Jews, Christians, and Muslims, something that is not owned by the other prophets. The three religious adherents have their own story about Abraham based on their own holy scriptures. This article deals with one side of Abraham's life history, namely how Abraham conveid God's message to his nation. This problem will be discussed in the Islamic perspective, with reference to the Koran as its main source.

Key Word: Abraham, Alquran, preaching

\section{INTRODUCTION}

One of the miracle sides of Alquran is its report about mysterious things. "Mysterious" in this context means everything beyond the knowledge of Prophet Muhammad P.B.U.H. One of this 
"mysterious" things is the story of the past people. In other words, the story of the past people recorded in Alquran became one of the miracle sides of Alquran which finally was an assertion of originating Alquran from Allah, and not Muhammad creation (Muslim, 1996: 179-181).

According to Abū Zahrah (1980: 145), one of the miracle sides of the stories of Alquran is its "real", which means that it is really existed in the past to become lessons and advices for moslems. In the same meaning, Manna' al-Qattān (2000: 16) stated that the stories of Alquran is not imaginary. They were really happened in the history of people which then expressed by Alquran with amazing style.

One of the stories in Alquran is the story of Prophet Abraham. This story recorded in many chapters of Alquran. This article tries to trace the record of Alquran about preaching done by Prophet Abraham.

\section{WHO IS ABRAHAM?}

Many historians stated that Abraham had lineage which be connected to Prophet Noah. The lineage of Prophet Abraham was: Abraham bin Azar bin Nahur bin Saruj bin Ra'w bin Falih bin 'Abir bin Syalih bin Irfiksyadz bin Sam bin Noah. This means that Prophet Noah was the $9^{\text {th }}$ grandfather of Prophet Abraham (al-Syahat, 1991: 16). In othe place, Syarqāwi (1970: 144), citing Yosebus--a Greec Christian historian--stated that the name of Abraham's father was Atsar. This name was a name of old Pharisian language which meant fire.

Prophet Abraham, as written by Farid Wajdi (1971: 10), was born in the city of Ur, the region of Babilonia, in 2000 BC. Adding this information, al-Syahat stated that Abraham was born when his father was 75 years old (1991: 17). Abraham is the oldest of his father's sons. After Abraham there was two children i.e. Nahur and Harran. The last mentioned was father of Prophet Luth. Abraham was the $9^{\text {th }}$ Sam generation.

The society faced by Abraham was the people of idol worshippers. Abraham's father is one of those idols suppliers. While his father and his people worshipped idols, Abraham was fully aware that the idols were not apropriate to be worshipped, because they had no any power (Syarqāwìi, 1970: 144-145). 
In this decadence sphere, Abraham grew up with different way from his generation. Allah has preapred him to become His messanger. The young Abraham extremely hated those idols. In his consciousnes, he believed that those idols had no any power to give any advantage or disadvantage to people. He believed only one God in this universe, i.e. Allah swt.

Allah has sent Abraham out to call his people to worship only Him. Abraham began his preaching to the nearest people, i.e. his father, his family, his clan, and his people. Abraham preached his appeal gently and clearly. But he just found rejection more and more.

Abraham then believed that the mild manner he did in his dakwah did not produce any advantegs. He then decided to do something like shock theraphy to his people. He planned to destroy idol gods of his people, which then bring him to the criminal court and face the fire condemnation.

After the massive efforts he did in preaching his people to the tauhid conviction, but without success result, then by Allah's willing, Abraham, together with his wife, Sarah, and his nephew, Loth, left his country Haran migrating to Palestina which at that time occupied by Kan'an race. They lived in a city called Nablus (Syarqāwi, 1970: 149).

Because of the rejection and antipathy of Palestinian people, finally Abraham together with his group left the country toward Egypt region. For a long time, Abraham lived in this country prosperously. The King of Egypt presented him an Egypt maiden called Hajar. Sarah was aware of her lack of her inability to give Abraham a son. Then she initiated to order Abraham to marry Sarah. It is from this Hajar, that Abraham got a son called Ismail.

The excessive envious of Sarah to Hajar, made Abraham evacuate his second wife, Hajar together with their son, Ismail, to an infertile, dry, and unoccupied Mecca. Abraham than came back to Palestina, but he did not forget to entrust his family to Allah. Allah then made Abraham's prayer come true. Mecca became a fertile, thriving, and prosperous country as the effect of Zam-Zam Well. Mecca then became a destination of travelers. After a long time, Abraham visited his wife and his son. Here, Allah asked Abraham to slaughter his lovely son, Ismail. The obedience of Abraham to his 
God is stronger than his love to the son, and then he did the God's command. But when he begin to slaughter the neck of his son, then suddenly it is not the neck of his son spurting a blood, but it is the neck of a big sheep.

In one of his visiting Hajar and Ismail in Mecca, Abraham was ordered by Allah to construct Ka'bah. Supported by Ismail, Abraham built Ka'bah with great enthusiasm. After constructing Ka'bah, Abraham invited his people to visit it .

Once more, Allah gave His benefit to Abraham with the birth of Ishak from Sarah's womb in 1896 BC. after the event of slaughtering Ismail. Finally, in 1773 BC. God has teken Abraham unto Him.

\section{ABRAHAM'S PREACHING IN ALQURAN}

Before studying how Alquran recorded Abraham's preaching to his people, the writer, for the first time, want to make a confirmation that Alquran is not a historical book. Alquran is not and always not in the position of a book that narrates any story--without exception-from A to Z. 'Story' in the term of Alquran is qișsah which lexically originated from qoshsho yaqushshu that meant to clip (in Alquran there are many expressions that caontained the words of yaqușsu, naqușșu, qașașna which meant to narrate). Qișsah is really something like construction of clippings. It meant that stories which presented by Alquran were not complete. It presented in the forms of story clippings that were needed to become a lesson for moslems. Story in Alquran, from the first time, was not intended to become a complete historical record, because Alquran, once again, is not a historical book. It was just a construction intentionally used to reach a certain message.

In Alquran, the story of Abraham's preachings was not only found in one chapter, but also in many other chapters. Simply, the preachings of Abraham can be divided into two groups; the first is Abraham's preaching specifically for his father, and the second is Abraham's preaching to his father together with his people.

\section{Abraham's Preaching to His Father}

It was stated in Chapter Maryam: 41-50 :

Translation: 
"(Also mention in the Book (the story of) Abraham: He was a man of Truth, a prophet. Behold, he said to his father: "O my father! why worship that which heareth not and seeth not, and can profit thee nothing? "O my father! to me hath come knowledge which hath not reached thee: so follow me: I will guide thee to a way that is even and straight. O my father! serve not Satan: for Satan is a rebel against (Allah) Most Gracious. O my father! I fear lest a Penalty afflict thee from (Allah) Most Gracious, so that thou become to Satan a friend. (The father) replied: "Dost thou hate my gods, O Abraham? If thou forbear not, I will indeed stone thee: Now get away from me for a good long while! Abraham said: "Peace be on thee: I will pray to my Lord for thy forgiveness: for He is to me Most Gracious. And I will turn away from you (all) and from those whom ye invoke besides Allah: I will call on my Lord: perhaps, by my prayer to my Lord, I shall be not unblest. When he had turned away from them and from those whom they worshipped besides Allah, We bestowed on him Isaac and Jacob, and each one of them We made a prophet. And We bestowed of Our Mercy on them, and We granted them lofty honour on the tongue of truth".

These verses narrated how Abraham did the dialogue with his father. This dialogue happened between a son who was a prophet with his father who was infidel (diametrically opposites to the dialogue in Chapter Hud: 42-43, between a father who was prophet called Noah, with his infidel son called Kan'an).

In this dialogue between Abraham and his father, we find many lessons about how should dialogue runs between two people who have different conviction. Openly, we find these lessons as follow:

The first lesson is, that dialogue must be run softly whatsoever the partner of dialogue is. The dialogue between Abraham and his father is about a principal thing, i.e. belief and unbelief. Both of them are diametrically different one another. But in this dialogue, Abraham could show his amazing polite to his father. He began his call with this expression: "ya abati" (O my father). This call showed clearly Abraham's respect to his father. Alquran recorded that Abraham did this call four times which maybe aimed to find his father's acceptance. If for the first call his father did not yet accept, maybe for the furthermore call, he will accept Abraham's call.

This dialogue did not finish in a happy ending as Abraham imagined. Even, his father intimidated his son as recorded by Alquran in chapter Maryam: 46 :

Translation: 
(The father) replied: "Dost thou hate my gods, O Abraham? If thou forbear not, I will indeed stone thee: Now get away from me for a good long while!

But Abraham replied and closed this dialogue with a good expression, as stated in chapter Maryam: 47:

Translation :

(The father) replied: "Dost thou hate my gods, O Abraham? If thou forbear not, I will indeed stone thee: Now get away from me for a good long while".

This good expression and reply from Abraham became a good lesson for moslem today. It is really the teaching of Alquran that dakwah must be delivered softly and kindly as stated in Alquran chapter al-Nahl : 125 :

Translation :

"Invite (all) to the Way of thy Lord with wisdom and beautiful preaching; and argue with them in ways that are best and most gracious: for thy Lord knoweth best, who have strayed from His Path, and who receive guidance".

Even, Allah ordered Musa and Harun to speak friendly and kindly to Fir'aun as stated in Alquran chapter Toha: 44 :

Translation:

"But speak to him mildly; perchance he may take warning or fear (Allah)."

It is then become clear for us, that Alquran taught us speaking mildly to any person who have different conviction from us. To speak roughly is not teaching of Alquran in any way.

The second lesson is, that we have to open the dialogue well. In this case Abraham presented a disaffirmative question to his father as recorded in chapter Maryam: 43 :

Translation:

"O my father! why worship that which heareth not and seeth not, and can profit thee nothing?

This style of expression from Abraham is a good and beautiful expression which forced the second person (mukhatab) to think correcltly by himself to get the truth. So he (second person) felt nothing that he was taught, or was considered as a foolish man, that can stagnated the dialogue.

The third lesson is, we must begin (and even narrowed down) dialogue only in significant and essential thing, and not insignifant 
and non-essential one. To worship only Allah is the goal of human creation (see chapter al-Zariyat: 56). Invitation to worship only Allah is invitation of all prophets, so did Abraham.

The fourth lesson is, that we have to use an axiomatic fact in dialogue. The idols worshipped by Abraham people were things made from stone which had no any power to hear prayer, to understand praise, to response request, to see obedience of their worshippers, etc. Accordingly, these idols were not appropriate to be god in any way. Abraham propose a disaffirmative question to his father why he worshipped something did not hear and did not see.

By this disaffirmative question, Abraham wanted to teach his father using his intellect to understand this matter. He wanted his father wake up from a long standing sleep of uncritical faith following the forefather.

\section{ABRAHAM'S PREACHING TO HIS FATHER AND PEOPLE}

There are six group of verses in six chapters in Alquran which narrated this case. These six groups of verses are chapter al-Syu'ara: 69-89; chapter al-Shaafaat: 83-100; chapter al-Anbiya: 51-73; chapter al-Ankabut: 16-27; chapter al-Baqarah: 258; and chapter al-An'am: 74-81.

Generally, these verses contained Abrahams call to his people to leave worshipping idols toward worshipping only Allah. From these verses we understand Abraham method in delivering his teachings. He opened his call with a disaffirmative question to excite his people awarness from an absent-minded. He asked the substance of their people idols, as Alquran recorded in following verses.

Behold! he said to his father and his people, "What are these images, to which ye are (so assiduously) devoted?" (al-Anbiya: 52)

And rehearse to them (something of) Abraham's story. Behold, he said to his father and his people: "What worship ye?" (al-Syu'ara: 69-70)

Behold! he said to his father and to his people, "What is that which ye worship? (al-Shaafaat: 85)

Answering this questions, Abraham's people gave a very weak argumentation that they just followed their forefathers without reserve. In this case they said: 
They said, "We found our fathers worshipping them." (alAnbiya: 53)

They really knew that these idols had not anything to give advanteage or disadvantage to people. But the blind mind made them ignore the truth. And this resistance attitude of his people made Abraham angry. He wanted to teach his people a real lesson that their idols is nothing. These idols really were not able to help themselves, let alone to help people. One day, when his people made a party, Abraham move stealthily to their altar, and began to destroy the idols one after the other. He just left one idol untouched, the biggest one. In this case Alquran recorded :

So they turned away from him, and departed. Then did he turn to their gods and said, "will ye not eat (of the offerings before you)?... "What is the matter with you that ye speak not (intelligently)?" Then did he turn upon them, striking (them) with the right hand. (al-Shafat: 90-93)

"And by Allah, I have a plan for your idols - after ye go away and turn your backs. So he broke them to pieces, (all) but the biggest of them, that they might turn (and address themselves) to it". (al-Anbiya: 57-58)

The party has finished, then the people bent their steps toward the altar. There, they were shocked to see their gods had been destroyed. And they began to search for the actor of this excessive crime. Then Abraham's name was mentioned as the actor of this crime, so they catched him. And happened this dialogue:

They said, "Art thou the one that did this with our gods, O Abraham? He said: "Nay, this was done by - this is their biggest one! ask them, if they can speak intelligently. So they turned to themselves and said, "Surely ye are the ones in the wrong! Then were they confounded with shame: (they said), "Thou knowest full well that these (idols) do not speak!" (Abraham) said, "Do ye then worship, besides Allah, things that can neither be of any good to you nor do you harm?"Fie upon you, and upon the things that ye worship besides Allah! Have ye no sense?"..(al-Anbiya: 62-67)

Actually they recognized the truth of Abraham argumentation. But the blind mind have covered up their soul. Then they brought him to the criminal court and faced him to the fire condemnation, but Allah saved his prophet. 
So naught was the answer of (Abraham's) people except that they said: "Slay him or burn him." But Allah did save him from the Fire. Verily in this are Signs for people who believe". (al-Ankabut: 24)

From this Alquran's illustration about Abraham's preaching to his people, we can notice following cases:

First, the dialogue between Abraham and his people related to the principal thing, i.e. the worship of Allah.

Second, dialogue was the method of prophets in debate. This method could eliminate the mist that covered the intellect, so that someone would get the truth by himself.

Third, the attitude of blind mind just make intellect die, cover the truth, and direct to digression.

Fourth, the goal of dakwah is to explain the truth, to give the power argumentation, and not to force that truth.

Fifth, to use the power incorrectly never eliminate the truth. It just show the weak of argumentation in debate. The truth can be restricted, but can not be eliminated.

\section{CONCLUSION}

The story in Alquran aimed to become lesson for moslem. The story of Abraham, like other prophetic stories in Alquran, is the story of delivering call for the truth. Abraham's preaching, like other prophets', met many problems. This is will become a lesson for prophet Muhammad P.B.U.H., that in delivering the truth, all prophets faced many kind of problems. It is hoped that Muhammad would have enough power and patience to face the problems. Wallahu A'lam

\section{BIBLIOGRAPHY}

Alquran al-Karīm

Abū Syatit al-Syahat, Muhammad. 1991. Khașāiṣ Nażm al-Qur'ān Fī Qișșah Ibrāhīm.. First Edition. Kairo: Matba'ah Amānah.

Abu> Zahrah, Muh\}ammad. 1980. Alqur'ān al-Mu'jizat al-Kubrā, Beirūt: Dār al-Fikr.

Muslim, Muṣtafā. 1996. Mabāhis̉ Fī I'jāz al-Qur'ān. Second Edition. Riyad\}: Dār al-Muslim. 
Jurnal Hunafa, Vol. 7, No. 2 Desember 2010:135-144

Al-Syarqāwī, Muḥammad bin Abdurrahmān. 1970. Al-Anbiyā Fì al-Qur'ān al-Karīm. Kairo: Dār al-Sya'b.

al-Qatțān, Manna'. 2000. Mabāhiṣ fī 'Ulūm al-Qur'ān. Eleventh Edition. XI. Kairo: Maktabah Wahbah.

Wajdī, Muhammad Farid. 1971. Dā'irah al-Ma'ārif al-Qarn al-'Isyrīn. Third Edition. Beirūt: Dār al-Ma'rifah. 